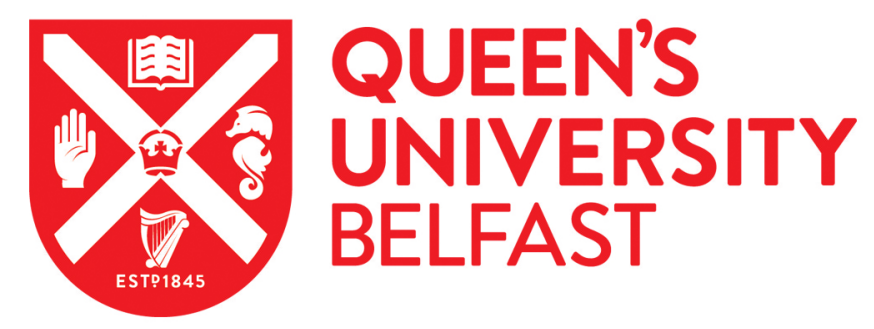

\title{
Replication of the association of GLT6D1 with aggressive periodontitis in a Sudanese population
}

Hashim, N. T., Linden, G. J., Ibrahim, M. E., Gismalla, B. G., Lundy, F. T., Hughes, F. J., \& El Karim, I. A. (2015).

Replication of the association of GLT6D1 with aggressive periodontitis in a Sudanese population. Journal of Clinical Periodontology, 42(4), 319-324. https://doi.org/10.1111/jcpe.12375

Published in:

Journal of Clinical Periodontology

Document Version:

Peer reviewed version

Queen's University Belfast - Research Portal:

Link to publication record in Queen's University Belfast Research Portal

Publisher rights

(C) 2015 John Wiley \& Sons.

This is the peer reviewed version of the following article: Hashim NT, Linden GJ, Ibrahim ME, Gismalla BG, Lundy FT, Hughes FJ, EI Karim IA. Replication of the association of GLT6D1 with aggressive periodontitis in a Sudanese population. J Clin Periodontol 2015; 42: 319-324., which has been published in final form at http://onlinelibrary.wiley.com/wol1/doi/10.1111/jcpe.12375/abstract

This article may be used for non-commercial purposes in accordance with Wiley Terms and Conditions for Self-Archiving.

\section{General rights}

Copyright for the publications made accessible via the Queen's University Belfast Research Portal is retained by the author(s) and / or other copyright owners and it is a condition of accessing these publications that users recognise and abide by the legal requirements associated with these rights.

Take down policy

The Research Portal is Queen's institutional repository that provides access to Queen's research output. Every effort has been made to ensure that content in the Research Portal does not infringe any person's rights, or applicable UK laws. If you discover content in the

Research Portal that you believe breaches copyright or violates any law, please contact openaccess@qub.ac.uk. 
Replication of the association of GLT6D1 with aggressive periodontitis in a Sudanese population

Running Title: Genetic variants and AgP in Sudan

Authors: N.T. HASHIM, ${ }^{1}$ G.J. LINDEN, ${ }^{2}$ M.E. IBRAHIM, ${ }^{3}$ B.G. GISMALLA, ${ }^{1}$ F.T. LUNDY, ${ }^{4}$ F.J. HUGHES ${ }^{5}$ and I. A EI KARIM ${ }^{4}$

${ }^{1}$ Faculty of Dentistry, University of Khartoum, Khartoum, Sudan

${ }^{2}$ Centre for Public Health, Queen's University of Belfast, Belfast, United Kingdom.

${ }^{3}$ Institute of Endemic diseases, University of Khartoum, Khartoum, Sudan

${ }^{4}$ Centre for Infection and Immunity, Queen's University of Belfast, Belfast, United Kingdom

${ }^{5}$ Dental Institute, Kings College London, London, United Kingdom

\section{Corresponding author: Dr. Ikhlas El Karim}

Centre for Infection and Immunity, School of Medicine, Dentistry and Biomedical Sciences, Queen's University Belfast, Third Floor, Health Sciences Building, 97 Lisburn Road, Belfast, BT9 7AE, Northern Ireland, United Kingdom

Key words: Aggressive periodontitis, gene polymorphism, Africans 


\section{Abstract}

Background: Susceptibility to aggressive periodontitis $(\mathrm{AgP})$ is influenced by genetic as well as environmental factors. Studies linking gene variants to AgP have been mainly centred in developed countries with limited data from Africa.

Aim: To investigate whether previously reported candidate gene associations with AgP could be replicated in a population from Sudan.

Methods: The investigation of case-control samples. Cases with $\mathrm{AgP}(\mathrm{n}=132)$ were identified from patients attending the Periodontal Department in Khartoum Dental Hospital. Age and sex matched controls $(n=136)$, with no evidence of periodontitis, were recruited from the same hospital. Genotyping was performed using the Sequenom MassARRAY iPLEX platform. Analysis focused on gene variants with a minor allelle frequency (MAF) > $25 \%$ in the Sudanese subjects that had previously been reported to be associated with AgP. Results: One candidate gene rs1537415 (GLT6D1) was significantly associated with AgP, $\mathrm{OR}=1.50(95 \% \mathrm{Cl} 1.04-2.17), p=0.0295$ (increasing to $p=0.09$ after correction for multiple testing). The association strengthened to $\mathrm{OR}=1.56(95 \% \mathrm{Cl} 1.15-2.16), p=0.0042$ when the controls were supplemented with data from the Hap map for the Yoruba in Ibadan $(n=147)$ and remained significant $(p=0.013)$ after correction for multiple testing.

Conclusion: The study independently replicated the finding that rs1537415, a variant in glycosyl transferase gene GLT6D1, is associated with AgP and provided the first report of genetic associations with AgP in a Sudanese population. 


\section{Clinical Relevance}

Scientific rationale for the study: Aggressive periodontitis is more prevalent among Africans than Europeans but studies on potential genetic risk factors for the disease in African populations are lacking.

Principal findings: We independently replicated in a Sudanese population the previous finding in a European study (Schaefer et al. 2010) that a variant in the glycosyl transferase gene GLT6D1 is associated with an increased risk of aggressive periodontitis.

Practical implications: The identification of genetic risk factors may help to facilitate more rational approaches to treatment through a better understanding of disease pathogenesis and an improvement in our ability to identify high-risk groups for periodontitis. 


\section{Introduction}

Periodontal diseases are opportunistic chronic infections characterized by inflammation and destruction of the supporting tissues of the affected teeth. Periodontal diseases affect up to $90 \%$ of the adult population but only about $10 \%$ are highly susceptible to severe disease (Kassebaum et al. 2014). Included in those with high susceptibility are individuals who suffer severe destructive periodontal disease in early life and this clinical condition has been defined as aggressive periodontitis (AgP) (Tonetti \& Mombelli 1999). AgP is characterized by onset at a young age, rapid periodontal attachment loss with alveolar bone destruction and a tendency to aggregate in families (Tonetti \& Mombelli 1999, Llorente \& Griffiths 2006). The disease is caused by anaerobic Gram-negative bacteria but disease susceptibility can be influenced by genetic as well as environmental factors (Pihlstrom et al. 2005). Genetically determined variances in the host response to bacterial infections are important determinants for risk of periodontitis (Divaris et al. 2013). Numerous genetic association studies have indicated a possible role for genes encoding proteins associated with the immune response in the susceptibility to periodontitis (Laine et al. 2012). It has been shown that individuals from different populations carry different profiles of genetic variants and there may be substantial geographic differentiation (The 1000 Genomes Project Consortium 2012). Since genotype and allele frequencies can vary between different ethnic populations therefore a genetic risk factor for disease susceptibility in one population may not be a risk factor in another population (loannidis 2003, Loos et al. 2005, Meng et al. 2007).

A recent systematic review concluded that the prevalence of $\mathrm{AgP}$ varies among different ethnicities and is highest in African populations and their descendants (Susin et al. 2014). The prevalence of $\mathrm{AgP}$ in Caucasians residing in north and mid-Europe is $0.1 \%$ and in south European populations is higher $\sim 0.5 \%$ (Susin et al. 2014). There are higher prevalence rates 
for AgP in African populations ranging from $0.5 \%$ to $5 \%$ (Albandar \& Tinoco 2002). A study of high school students in Sudan reported that 3.4\% had AgP (Elamin et al. 2010). To date, data linking gene variants to $\mathrm{AgP}$ in native African populations is sparse. The greater genetic diversity of African populations present challenges, however, it is important to conduct genetic studies in Africa (Teo et al. 2010). It was hypothesized that variants in candidate genes shown to be associated with $\mathrm{AgP}$ in studies in developed countries could also be associated with this condition in African populations. The aim of this study was to investigate whether previously reported candidate gene associations with $\mathrm{AgP}$ could be replicated in a population from Sudan.

\section{Subjects and methods}

\section{Study participants}

Cases and controls were recruited from patients attending the Department of Periodontology Faculty of Dentistry, University of Khartoum and Khartoum Teaching Dental Hospital. Cases with AgP were identified on the basis of a number of criteria including age, severity of interproximal periodontal attachment loss and alveolar bone loss as shown in table 1. Individuals were examined under ideal conditions in a dental chair by an experienced specialist periodontist (N.T.H.). Full-mouth measures of probing pocket depths (PPD) and clinical attachment levels $(\mathrm{CAL})$ were obtained at 6 points per tooth (mesio-buccal, mesiolingual, disto-buccal, disto-lingual, buccal and lingual). Radiographic examination, which included an orthopantomogram and intraoral views, was also performed for each subject with a clinical diagnosis of AgP to confirm the diagnosis (Table 1). Control subjects were recruited from patients attending non periodontal clinics in the same hospitals who were frequency matched for age, sex and ethnicity, based on ethnic origin by tribe, to those recruited with AgP. The controls in some cases had evidence of gingival inflammation but were free from $\mathrm{AgP}$ as well as chronic periodontitis with no PPD or CAL >3mm. 
Demographic data including age, gender, tribal affiliation and information regarding smoking were obtained from all potential participants. Subjects were excluded if they were not Sudanese nationals; had diseases or conditions that could pose health risks to the participants or examiners; had medical conditions, identified by self-report, such as diabetes or neutropenias that could influence their periodontal condition; had received a course of antibiotics within the previous month; or had received periodontal treatment before sampling.

The study was approved by the Faculty of Dentistry, University of Khartoum Health Research Ethics Committee (HREC assigned number 1/2008). Informed written consent was obtained from each subject prior to participation in the study.

\section{Blood sample collection and genomic DNA preparation}

Four $\mathrm{ml}$ of venous blood was collected via venipuncture from the antecubital fossa into a 5 ml EDTA tube from each subject diagnosed with AgP and each control. DNA was extracted from blood samples using Qiagen DNeasy, DNA extraction kit (Qiagan, Hilden, Germany) at the Institute for Endemic Diseases, University of Khartoum. Genomic DNA was then quantified by Nanodrop (ND-1000, USA) and stored at $-80^{\circ} \mathrm{C}$ prior to transfer to Northern Ireland for genotyping.

\section{SNP Genotyping}

Genotyping was carried out at the genomic core unit at Queen's University Belfast. The genotyping was performed using a commercially available Sequenom MassARRAY iPLEX platform (Sequenom Inc., USA). The assay is based on a primer extension method and consists of an initial locus specific PCR reaction followed by a locus specific primer extension reaction in which an oligonucleotide primer anneals immediately upstream of the polymorphic site being genotyped. The primer and amplified target DNA were incubated with mass-modified dideoxynucleotide terminators. The primer extension was made according to 
the sequence of the variant site and is a single complementary mass-modified base. The mass of the extended primer was determined by MALDI-TOF mass spectrometry.

\section{SNPs investigated}

The cases and controls were genotyped for SNPS that had been investigated previously for associations with periodontitis. Some SNPs had been investigated in AgP while others had been studied in chronic periodontitis (Tables 2, S1).

In order to investigate possible replication of common variants previously reported to be associated with AgP the following inclusion criteria were applied. The SNPs included in the final statistical analysis had:

- Previously been reported to have an association with AgP.

- $\quad$ Minor allelle frequency (MAF) in the Sudanese controls studied of $>25 \%$.

- Genotype call rate of $>95 \%$.

\section{Population stratification}

The population substructure was estimated using the programme STRUCTURE 2.3.4. The STRUCTURE parameters were 10,000 burn-in periods and 10,000 step chains with up to 3 populations assumed $(\mathrm{K} 1-\mathrm{K} 3)$ and 10 replicates were run for each $K$.

\section{Statistical analysis}

Based on the number of cases and controls a post hoc analysis found the study had $80 \%$ power to detect an odds ratio (OR) of 1.7 for an association with $\mathrm{AgP}$. A secondary analysis in which the controls were supplemented with data available from the Hapmap for the Yoruba in Ibidan, Nigeria (International HapMap Project 2014) had 82\% power to detect an odds ratio of 1.59 which was the overall OR from the GWAS completed by Schaefer et al. (2010). 
Deviation of genotype frequencies from Hardy-Weinberg equilibrium (HWE) was assessed with Haploview 4.2 with a cut off of $p<0.05$. Only those SNPs that were in HWE were studied further.

Associations with AgP were examined using Haploview 4.2. Pearson's Chi Square was used to test associations between the allele frequencies and $\mathrm{AgP}$ with the significance level set at $p<0.05$. OR and $95 \%$ confidence intervals $(95 \% \mathrm{Cl})$ were calculated to report the strength of associations. A Bonferroni correction was applied to take multiple testing into account.

\section{Results}

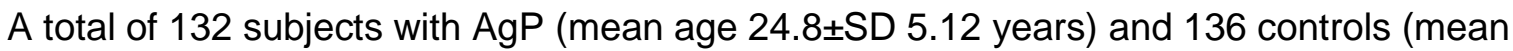
age 23.6 \pm SD 5.08 years) were investigated. The majority of the study populations were females (76\% cases, $73 \%$ controls). All subjects were non-smokers. There were 3 SNPs which met the inclusion criteria for the study (Table 2) and one of these was significantly associated with AgP namely rs1537415 (GLTD6D1).

rs1537415 (GLTD6D1)

The MAF for rs 1537415 was $37.8 \%$ in AgP cases compared with $28.8 \%$ in controls, $p=0.0295, \mathrm{OR}=1.50(95 \% \mathrm{Cl} 1.04-2.17)$. The test for trend was also significant $p=0.035$. Using a multiplicative model the odds of $\mathrm{AgP}$ in an individual who was homozygous for the $\mathrm{G}$ allele was 2.25. The association was no longer significant after application of a Bonferroni correction for multiple testing $(p=0.09)$. To further explore the associations data from the Hapmap for the Yoruba in Ibadan (YRI) were used to supplement the control genotypes. The MAF for $r s 1537415$ for the Yoruba $(n=147)$ was $26.9 \%$ which was similar to the value for the Sudanese controls (28.8\%). This secondary analysis increased the strength of the association with $p=0.0042$ and a final $\mathrm{OR}=1.56(95 \% \mathrm{Cl} 1.15-2.16)$. The association for 
GLT6D1 remained significant after application of a Bonferroni correction for multiple testing $(p=0.013)$.

\section{Other variants}

The genotype data for those SNPs which did not meet the inclusion criteria are shown in supplementary data (Table S1). Two of these SNPS were significantly associated with AgP in the Sudanese population namely rs16944 (IL1beta -511) and rs4986790 (TLR4 896).

The MAF for rs 16944 was $36.8 \%$ in AgP cases compared to $46.2 \%$ in controls, $p=0.0295$, $\mathrm{OR}=0.68(95 \% \mathrm{Cl} 0.48-0.96)$. The test for trend was also significant, $p=0.0323$. The addition of Hapmap genotype data for the YRI $(n=147)$, which had a MAF of $39.5 \%$ in relation to rs 16944 , resulted in a weakening of the association for this variant and a loss of significance with $p=0.115, \mathrm{OR}=0.78(95 \% \mathrm{Cl} 0.58-1.06)$.

The rare variant rs4986790 was significantly associated with $\mathrm{AgP}, p=0.0053, \mathrm{OR}=2.19(95 \%$

$\mathrm{Cl} 1.21-3.83$ ). This was a low frequency variant (MAF AgP cases $=16.1 \%$, MAF controls= 8.1\%). Analysis with the addition of the Hapmap YRI data $(n=146)$, which had a MAF of $4.1 \%$, strengthened the association for $r 4986790$ with $p=<0.0001, \mathrm{OR}=3.02(95 \% \mathrm{Cl} 1.86$ 4.93).

\section{Population stratification}

Analysis of the genotype data, from SNPS which were in HWE, in the programme STRUCTURE divided the study population into three defined clusters which showed within and between cluster homogeneity (Figure S1).

\section{Discussion}

The main finding of this study was that a genetic variant in the glycosyl transferase gene GLT6D1 was associated with aggressive periodontitis in a Sudanese population. In the 
primary analysis the association became non significant after Bonferroni correction for multiple testing $(p=0.09)$. This association was significant after a secondary analysis that incorporated data from the Hapmap for the Yoruba in Ibidan (International HapMap Project 2014) to supplement the controls. Indeed the association of this variant in GLT6D1 was strengthened after incorporating the Hapmap data and remained significant after correction for multiple testing $(p=0.013)$. The finding independently replicated the identification of rs1537415 as a candidate genetic variant in one of the few GWAS of AgP (Schaefer et al. 2010) reported to date.

Genome-wide studies are effective at detecting common variants of reasonable effect size, odds ratios greater than 1.2, that contribute to complex traits (Flint \& Kendler 2014). The GWAS completed by Schaefer et al. (2010) identified a variant in the glycosyltransferase gene GLT6D1 to be associated with AgP in German cases. The association was replicated in a panel of Dutch generalized and aggressive periodontitis cases. The odds ratio for the association reported by Schaefer et al. (2010) was 1.59 (95\% Cl 1.36-1.86), which was similar to the result from the final model used in the current study of 1.58 . There was enrichment of the minor allele by $9 \%$ in the Sudanese population which was broadly similar to that reported by Schaefer et al. (2010) of about $10 \%$. Schaefer et al. (2010) suggested a possible functional role for rs 1537415 was the reduction of the binding affinity of GATA-3 which is important for T cell development, homeostasis, activation, proliferation and effector functions of (Zheng \& Flavell 1997, Wan 2014).

There are a number of limitations including the small size of the population investigated which indicate the pilot nature of this study. In order to improve the power of the study the controls were supplemented with genotype data from the Hapmap for the Yoruba in Ibidan (International HapMap Project 2014). Despite being a more common condition than in Western Europe the prevalence of $\mathrm{AgP}$ in Africa is low and so it was felt that this could be justified. Adjustment for age and gender did not change the outcomes of the primary 
analysis, however, it was not possible to adjust for these factors in the larger secondary analysis incorporating Hapmap data. Furthermore, the analyses were not adjusted for possible confounders such as BMI or socioeconomic factors, however, there is limited information that these have been identified as significant risk factors for AgP. Smoking was not a consideration as none of the cases or controls smoked.

To further acknowledge the size of the study we focused principally on common variants with a MAF $>25 \%$. This value was chosen to improve the power of replicating any association of the variants being studied with the complex phenotype of $\mathrm{AgP}$ (see discussion in Ardlie et al. 2002). The genotyping platform used also provided data on variants which occurred with low frequency in African populations. There were also a number of variants which did not meet the inclusion criteria because previous reports did not find an association with aggressive forms of periodontitis. All the genotype data collected has been provided in a supplementary table so that other researchers can access it. In the analysis limited to SNPS in the supplementary group, rs16944 had a significant association with AgP in the Sudanese population. This variant, however, lost statistical significance when data from the Hapmap was used to supplement the control genotype data. The finding in relation to rs16944 in the sample recruited in Khartoum may therefore represent a false positive. A systematic review of cytokine gene polymorphisms in periodontal disease reported a weak positive association of rs16944 (IL1beta -511) with chronic but not aggressive periodontitis (Nikolopoulos et al. 2008).

A rare variant in the TLR4 gene rs 4986790 was also associated with an increased risk of $\mathrm{AgP}$. This finding is in line with previous reports linking rs4986790 with a pro-inflammatory phenotype in African populations (Ferwerda et al. 2007). TLR4 is a critical pathogen recognition receptor for lipopolysaccharide from Gram negative bacteria. Functionally, the rs4986790 variant exhibits an increased TNF- $\alpha$ cytokine response in vitro after stimulation 
with LPS and seems to predispose to septic shock in African populations (Ferwerda et al. 2007). In European, but not in African, populations rs4986790 is in linkage with another rare variant rs4986791 and this haplotype has little or no effect on responsiveness to LPS and the susceptibility to infections. It is probable that the findings of the present study represent a false positive association for the TLR4 SNP and this is supported by the contradictory reports of two European studies one reporting an increased (Brett et al. 2005) and the other a decreased risk of $\mathrm{AgP}$ (James et al. 2007) associated with this variant. Both the older studies as well as the current study were not adequately powered to identify a true association for this rare variant.

Genetic factors have been suggested to play a role in aggressive periodontitis but studies have been mainly limited to developed countries. The majority of GWAS have been based on European populations. GWA platforms have been designed for optimal use in European populations and are therefore less sensitive in non-European populations (Fu et al. 2011). However, although there are some population specific risk variants it is also the case that genetic variants identified with increased risk of complex traits, such as type 2 diabetes in European populations, have also been shown to be associated with increased risk in diverse racial and ethnic groups (Waters et al. 2010). It is acknowledged that there is great genetic diversity in African populations (DeGiorgio et al. 2009). There are more than 2000 distinct ethnic groups in Africa with evidence that these correlate with genetic differences. Accordingly the levels of population genetic structure are greater in Africa than in other parts of the world (Teo et al. 2010). In the current study population structure analysis using all the genotype data showed the presence of three distinct but homogenous clusters which mapped to the locally well recognized tribal groupings (Excoffier et al. 1991, Cavalli-Sforza 1997). There was no evidence of significant differences in genotype distribution in these clusters, however, the numbers in each cluster were small. It remains a possibility that we could not fully account for the population structure in the genotype analysis and this may have been a factor in the identification of departure from HWE in 3 variants. While 
population structure is a problem in such studies there are advantages to genetic studies in African populations. The low levels of linkage disequilibrium mean that a replication confirmed using African data may be of particular value as it is more likely to indicate a causal variant (Teo et al. 2010). Further studies in African populations with larger sample sizes and correction for population structure may be useful in fine mapping causal variants which have a role the complex pathophysiology of periodontitis.

\section{Conclusion}

This is the first study that validates the association of a variant in GLT6D1 with aggressive periodontitis in a population with a different ancestral background to North-Western Europeans. It is also the first report of genetic associations with aggressive periodontitis in a Sudanese population. The study provides pilot data that could be used to design larger studies to explore the genetic links to periodontal disease. 


\section{References}

Albandar, J.M. \& Tinoco, E. M. (2002) Global epidemiology of periodontal diseases in children and young persons. Periodontology 2000 29, 153-176.

Ardlie, K.G., Lunetta, K.L. \& Seielstad, M. (2002) Testing for population subdivision and association in four case-control studies. American Journal of Human Genetics 71, 304-311. Brett, P.M., Zygoogianni, P., Griffith, G.S., Tamaz, M., Parker, M., D’Aiuto, F. \& Tonetti, M. (2005) Functional gene polymorphisms in aggressive and chronic periodontitis. Journal of Dental Research 84, 1149-1153.

Cavalli-Sforza, L.L. (1997) Genes, people and languages. Proceedings of the National Academy Sciences of United States of America 94, 7719-7724.

Chen, L.L., Li, H., Zhang, P.P. \& Wang, S.M. (2012) Association between Vitamin D receptor polymorphisms and periodontitis: A meta-analysis. Journal of Periodontology 83, 1095-1103. DeGiorgio, M., Jakobsson, M. \& Rosenberg, N.A. (2009) Out of Africa: Modern human origins special feature: explaining worldwide patterns of human genetic variation using a coalescent-based serial founder model of migration outward from Africa. Proceedings of the National Academy of Science USA 106, 16057-16062.

Divaris, K., Monda, K. L., North, K. E., Olshan, A. F., Reynolds, L. M., Hsueh, W. C., Lange, E. M., Moss, K., Barros, S. P., Weyant, R. J., Liu, Y., Newman, A. B., Beck, J. D. \& Offenbacher, S. (2013) Exploring the genetic basis of chronic periodontitis: a genome-wide association study. Human Molecular Genetics 22, 2312-2324.

Elamin, A., Skaug, N., Ali, R.W., Bakken, V. \& Albandar, J. (2010) Ethnic disparity in the prevalence of periodontitis among high school students in Sudan. Journal of Periodontology 81, 891-896.

Excoffier, L., Harding, R.M., Sokal, R.R., Pellegrini, B. \& Sanchezmazas, A. (1991) Spatial differentiation of Rh and $\mathrm{Gm}$ haplotype frequencies in sub-Saharan Africa and its relation to linguistic affinities. Human Biology 63, 273-307.

Ferwerda, B., McCall, M.B.B., Alonso, S., Mouktaroudi, M., Giamarellos-Bourboulis, E.J., Izagirre, N., Syafruddin, D., Kibiki, G., Cristea, T., Hijmans, A., Hamann, L., Israel, S., 
Eighazali, G., Troye-Blomberg, M., Kumpf, O., Maiga, B., Dolo, A., Doumbo, O., Hermsen, C.C., Stalenhoef, A.F.H., van Crevel, R., Brunner, H.G., Oh, D.-Y., Schumann, R.R., de la Rua, C., Sauerwein, R., Kullberg, B.-J., van der Ven, A.J.A.M., van der Meer, J.W.M. \& Netea, M.G. (2007) TLR4 polymorphisms, infectious diseases, and evolutionary pressure during migration of modern humans. Proceedings of the National Academy of Sciences of the United States of America 104, 16645-16650.

Flint, J. \& Kendler, K.S. (2014) The Genetics of Major Depression. Neuron 81, 484-503. Hansen, B.F., Gjermo, P. \& Bergwitz-Larsen, K.R. (1984) Periodontal bone loss in 15 year old Norwegians. Journal of Clinical Periodontology 11, 125-133.

Fu, J., Festen, E.A. \& Wijmenga, C. (2011) Multi-ethnic studies in complex traits. Human Molecular Genetics 20, R206-R213.

Hodge, P.J., Teague, P.W., Wright, A.F., Kinane, D.F. (2000) Clinical and genetic analysis of a large North European Caucasian family affected by early-onset periodontitis. Journal of Dental Research 2000 79, 857-863.

International HapMap Project (2014) URL http://hapmap.ncbi.nlm.nih.gov/ (accessed 20 October 2014).

loannidis, J.P. (2003) Genetic association: false or true? Trends in Molecular Medicine 9, 135-138.

James, J.A., Poulton, K.V., Haworth, S.E., Payne, D., McKay, I.J., Clarke, F.M., Hughes, F.J. \& Linden, G.J. (2007) Polymorphisms of TLR4 but not CD14 are associated with a decreased risk of aggressive periodontitis. Journal of Clinical Periodontology 34, 111-117. Kassebaum, N.J., Bernabe, E., Dahiya, M., Bhandari, B., Murray, C.J.L. \& Marcenes, W. (2014) Global burden of severe periodontitis in 1990-2010: A systematic review and metaregression. Journal of Dental Research 93, 1045-1053.

Kronauer, E., Borsa, G. \& Lang, N. P. (1986) Prevalence of incipient juvenile periodontitis at age 16 years in Switzerland. Journal of Clinical Periodontology 13, 103-108. 
Laine, M.L., Crielaard, W. \& Loos, B. G. (2012) Genetic susceptibility to periodontitis. Periodontology 2000 58, 37-68.

Llorente, M.A. \& Griffiths, G.S. (2006) Periodontal status among relatives of aggressive periodontitis patients and reliability of family history report. Journal of Clinical Periodontology 33, $121-125$.

Loos, B.G., John, R.P. \& Laine, M.L. (2005) Identification of genetic risk factors for periodontitis and possible mechanisms of action. Journal of Clinical Periodontology 32, 159179.

Meng, H., Xu, L., Li, Q., Han, J. \& Zhao, Y. (2007) Determinants of host susceptibility in aggressive periodontitis. Periodontology 2000 43, 133-159.

Nikolopoulos, G.K., Dimou, N.L., Hamodrakas, S.J. \& Bagos, P.G. (2008) Cytokine gene polymorphisms in periodontal disease: a meta-analysis of 53 studies including 4178 cases and 4590 controls. Journal of Clinical Periodontology 35, 754-767.

Pihlstrom, B.L., Michalowicz, B.S. \& Johnson, N.W. (2005) Periodontal disease. Lancet 366, $1809-1820$.

Schaefer, A.S., Richter, G.M., Nothnagel, M., Manke, T., Dommisch, H., Jacobs, G., Arlt, A., Rosenstiel, P., Noack, B., Groessner- Schreiber, B., Jepsen, S., Loos, B.G. \& Scheriber, S. A. (2010) Genome-wide association study identifies GLT6D1 as a susceptibility locus for periodontitis. Human Molecular Genetics 19, 553-562.

Susin, C., Haas, A.N. \& Albandar, J.M. (2014) Epidemiology and demographics of aggressive periodontitis. Periodontology 2000 65, 27-45.

The 1000 Genomes Project Consortium (2012) An integrated map of genetic variation from 1,092 human genomes. Nature 291, 56-65.

Tai, H., Endo, M., Shimada, Y., Gou, E., Orima, K., Kobayashi, T., Yamazaki, K. \& Yoshie, H. (2002) Association of interleukin-1 receptor antagonist gene polymorphisms with early onset periodontitis in Japanese. Journal of Clinical Periodontology 29, 882-888. Teo, Y.-Y., Small, K.S. \& Kwiatkowski, D.P. (2010) Methodological challenges of genomewide association analysis in Africa. Nature Reviews Genetics 11, 149-160. 
Tonetti, M.S. \& Mombelli, A. (1999) Early-onset periodontitis. Annals of Periodontology 4, 39- 52.

Wan, Y.Y. (2014) GATA3: a master many trades in immune regulation. Trends in Immunology 35, 233-242.

Waters, K.M., Stram, D.O., Hassanein, M., Le Marchand, L., Wilkens, L.R., Maskarinec, G., Monroe, K., Kolonel, L., Altshuler, D., Henderson, B.E, \& Haiman, C.A. (2010) Consistent association of Type 2 Diabetes risk variants found in Europeans in diverse racial and ethnic groups. PLoS Genetics 6, e1001078.

Zheng, W.P. \& Flavell, R.A. (1997) The transcription factor GATA-3 is necessary and sufficient for Th2 cytokine gene expression in CD4 T cells. Cell 89, 587-596. 


\begin{tabular}{cccc}
\hline Age (years) & Number of teeth & Interproximal & Interproximal \\
& attachment loss & bone loss \\
& (non adjacent teeth) & $(\mathrm{mm})$ & $(\mathrm{mm})$ \\
\hline$<20$ & 2 & $>4$ & $>6$ \\
$<25$ & 3 & $>5$ & $>7$ \\
$<30$ & 5 & $>5$ & $>7$ \\
$<35$ & & & \\
& & & \\
& & & \\
\hline
\end{tabular}

Table 1. Criteria for diagnosis of aggressive periodontitis. Adapted from Hodge et al. 2000. 


\begin{tabular}{|c|c|c|c|c|c|c|}
\hline Genetic variant & $\begin{array}{c}\text { Historical study type } \\
\text { Authors }\end{array}$ & $\begin{array}{l}\text { HWE } \\
p \text { value }\end{array}$ & $\begin{array}{c}\% \\
\text { genotyped }\end{array}$ & $\begin{array}{l}\text { MAF } \\
\mathrm{AgP}\end{array}$ & $\begin{array}{c}\text { MAF } \\
\text { Control }\end{array}$ & $\begin{array}{c}\text { Unadjusted } \\
p\end{array}$ \\
\hline $\begin{array}{l}\text { rs4251961 } \\
(\text { IL1 RN) }\end{array}$ & 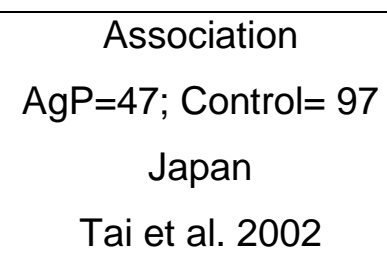 & 0.15 & 98.1 & 30.8 & 26.9 & 0.33 \\
\hline $\begin{array}{l}\text { rs10735810 } \\
\text { (VitD Fok 1) }\end{array}$ & $\begin{array}{l}\text { Meta-analysis } \\
\text { Chen et al. } 2012\end{array}$ & 0.29 & 97.4 & 22.5 & 26.3 & 0.31 \\
\hline $\begin{array}{l}\text { rs1537415 } \\
\text { (GLT6D1) }\end{array}$ & $\begin{array}{c}\text { GWAS } \\
\text { Schaefer et al. } 2010\end{array}$ & 0.39 & 97.0 & 37.8 & 28.8 & 0.0295 \\
\hline
\end{tabular}

Table 2. Single nucleotide polymorphisms included in the analysis of aggressive periodontitis in a Sudanese population. These variants had been shown to have an association with AgP in the historical studies outlined. In relation to 'Type of study' specific details of numbers of subjects involved and country of origin have only been given for association studies. 
Supplementary data

\begin{tabular}{|c|c|c|c|c|c|c|}
\hline $\begin{array}{l}\text { Genetic } \\
\text { variant }\end{array}$ & $\begin{array}{l}\text { Historical study type } \\
\text { Authors }\end{array}$ & $\begin{array}{c}\mathrm{HWE} \\
p \\
\text { value }\end{array}$ & $\begin{array}{c}\% \\
\text { genotype } \\
d\end{array}$ & $\begin{array}{l}\text { MAF } \\
\text { AgP }\end{array}$ & $\begin{array}{l}\text { MAF } \\
\text { Control }\end{array}$ & $\begin{array}{l}\text { Unadjusted } \\
\qquad p\end{array}$ \\
\hline $\begin{array}{c}\text { rs1800587 } \\
\text { (IL1alpha-889) }\end{array}$ & $\begin{array}{c}\text { Meta-analysis } \\
\text { Nikolopoulos et al. } 2008\end{array}$ & 0.19 & 98.1 & 36.4 & 36.5 & 0.99 \\
\hline $\begin{array}{l}\text { rs17561 } \\
\text { (IL1alpha } \\
\text { 4845) }\end{array}$ & $\begin{array}{l}\text { Meta-analysis } \\
\text { Mao et al. } 2013\end{array}$ & 0.11 & 98.5 & 24.4 & 21.6 & 0.44 \\
\hline $\begin{array}{c}\text { rs16944 } \\
\text { (IL1beta }-511)\end{array}$ & $\begin{array}{c}\text { Meta-analysis } \\
\text { Nikolopoulos et al. } 2008\end{array}$ & 0.69 & 97.8 & 36.8 & 46.2 & 0.0295 \\
\hline $\begin{array}{l}\text { rs1800872 } \\
\text { (IL10 -592) }\end{array}$ & $\begin{array}{l}\text { Meta-analysis } \\
\text { Zong et al. } 2012\end{array}$ & 0.27 & 97.8 & 41.5 & 40.9 & 0.89 \\
\hline $\begin{array}{c}\text { rs763780 } \\
\text { (IL17F ) }\end{array}$ & 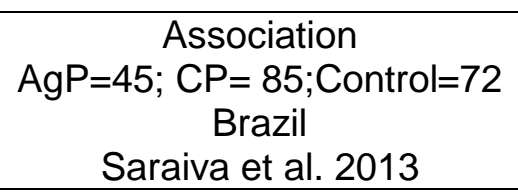 & 0.28 & 97.8 & 4.3 & 6.0 & 0.38 \\
\hline $\begin{array}{l}\text { rs7975232 } \\
\text { (VITD Apa1) }\end{array}$ & $\begin{array}{l}\text { Meta-analysis } \\
\text { Chen et al. } 2012\end{array}$ & 0.41 & 98.5 & 27.7 & 32.0 & 0.28 \\
\hline $\begin{array}{l}\text { rs1544410 } \\
\text { (VIT D Bsm1) }\end{array}$ & $\begin{array}{l}\text { Meta-analysis } \\
\text { Chen et al. } 2012\end{array}$ & 0.24 & 98.9 & 42.0 & 41.7 & 0.95 \\
\hline $\begin{array}{l}\text { rs731236 } \\
\text { (VIT D } \\
\text { 16Taq1) }\end{array}$ & $\begin{array}{l}\text { Meta-analysis } \\
\text { Chen et al. } 2012\end{array}$ & 0.38 & 98.5 & 45.4 & 40.2 & 0.22 \\
\hline $\begin{array}{l}\text { rs1800469 } \\
\text { (TGFbeta - }\end{array}$ & $\begin{array}{c}\text { Association } \\
\mathrm{AgP}=172 ; \mathrm{CP}=147 ; \text { Control }=\end{array}$ & 0.07 & 98.5 & 32.7 & 33.8 & 0.78 \\
\hline
\end{tabular}




\begin{tabular}{|c|c|c|c|c|c|c|}
\hline 509) & $\begin{array}{c}303 \\
\text { Brazil } \\
\text { Kobayashi et al. } 2009\end{array}$ & & & & & \\
\hline $\begin{array}{c}\text { rs1982037 } \\
\text { (TGFbeta 869) }\end{array}$ & $\begin{array}{c}\text { Association Kobayashi et al. } \\
2009\end{array}$ & 0.94 & 85.8 & 10.7 & 5.8 & 0.059 \\
\hline $\begin{array}{l}\text { rs1495741 } \\
\text { (NAT2) }\end{array}$ & $\begin{array}{c}\text { Association } \\
\text { Severe =74; Moderate = 48; } \\
\text { Health }=29 \\
\text { Germany } \\
\text { Kocher et al. } 2002 \text { * }\end{array}$ & 0.43 & 91.4 & 22.0 & 21.5 & 0.90 \\
\hline $\begin{array}{l}\text { rs1872426 } \\
\text { (OPG) }\end{array}$ & $\begin{array}{c}\text { Association } \\
\mathrm{AgP}=99 \text {; Control= } 89 \\
\text { Japan } \\
\text { Soedarsono et al. } 2006 \text { * }\end{array}$ & 0.58 & 95.1 & 21.4 & 22.4 & 0.79 \\
\hline $\begin{array}{l}\text { rs2277438 } \\
\text { (RANK L) }\end{array}$ & $\begin{array}{c}\text { Association } \\
\text { Soedarsono et al. } 2006 \text { * }\end{array}$ & 0.40 & 94.0 & 18.5 & 18.5 & 0.99 \\
\hline $\begin{array}{l}\text { rs3795391 } \\
\text { (S100a) }\end{array}$ & $\begin{array}{c}\text { Association } \\
\mathrm{AgP}=139 ; \text { Control }=88 \\
\text { China } \\
\text { Sun et al. } 2011\end{array}$ & 0.89 & 98.9 & 5.0 & 4.5 & 0.81 \\
\hline $\begin{array}{l}\text { rs4986790 } \\
\text { (TLR4 896) }\end{array}$ & $\begin{array}{c}\text { Meta-analysis } \\
\text { Ozturk et al. } 2009\end{array}$ & 0.57 & 95.1 & 16.1 & 8.1 & 0.0053 \\
\hline $\begin{array}{c}\text { rs6681231 } \\
\text { (COX-2) }\end{array}$ & $\begin{array}{c}\text { Association } \\
\mathrm{AgP}=532 ; \mathrm{CP}=1052 ; \\
\text { Control= } 2873 \\
\text { Germany/Holland } \\
\text { Schaefer et al. } 2010\end{array}$ & 0.33 & 81.6 & 31.6 & 31.3 & 0.96 \\
\hline
\end{tabular}

Table S1. Single nucleotide polymorphisms which did not meet the inclusion criteria for statistical analysis of aggressive periodontitis in a Sudanese population. In relation to 'historical study' specific details of numbers of subjects involved and country of origin have only been given for association studies. Two variants rs3795391 (S100a) and rs6681231 (COX-2) were shown to have an association with AgP whereas all other SNPs investigated 
either had an association with chronic periodontitis (CP) or no association with AgP or CP in the historical studies cited. There were 3 variants rs2227306 (IL8 -781), rs2275913 (IL17 A) and rs1360590 (CDKN2BAS) which showed departure from HWE and were not investigated further.

* The studies cited did not report on the specific SNP genotyped in the current study but on another variant in the gene. 


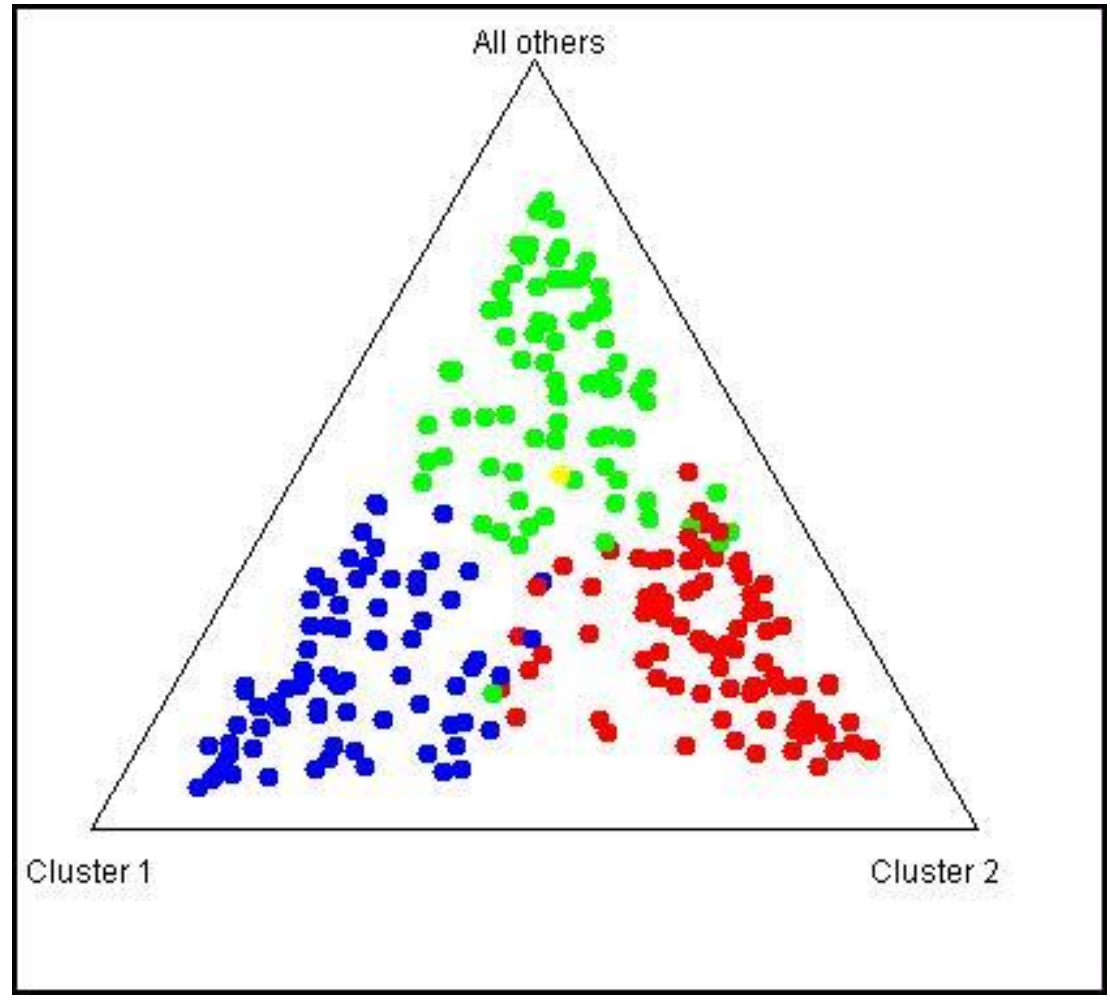

Figure S1. Plotted triangle showing population substructure of aggressive periodontitis cases and controls identified by the programme STRUCTURE. Analysis reveals presence of three different but homogenous substructures. 
Kobayashi, T., Nagata, T., Murakami, S., Takashiba, S., Kurihara, H., Izumi, Y., Numabe, Y., Watanabe, H., Kataoka, M., Nagai, A., Hayashi, J., Ohyama, H., Okamatsu, Y., Inagaki, Y., Tai, H. \& Yoshie, H. (2009) Genetic risk factors for periodontitis in a Japanese population. Journal of Dental Research 88, 1137-1141.

Kocher, T., Sawaf, H., Fanghanel, J., Timm, R. \& Meisel, P. (2002) Association between bone loss in periodontal disease and polymorphism of N-acetyltransferase (NAT2). Journal of Clinical Periodontology 29, 21-27.

Mao, M., Zeng, X.T., Ma, T., He, W., Zhang, C. \& Zhou, J. (2013) Interleukin-1 alpha-899 $(+4845) \mathrm{C} \rightarrow \mathrm{T}$ polymorphism increases the risk of chronic periodontitis: Evidence from a meta-analysis of 23 case-control studies. Gene 532, 114-119.

Ozturk, A. \& Vieira, A.R. (2009) TLR4 as a risk factor for periodontal disease: a reappraisal. Journal of Clinical Periodontology 36, 279-286.

Saraiva, A.M., Silva, M., Silva, J.D.C., da Costa, J.E., Gollob, K.J., Dutra, W.O. \& Moreira, P.R. (2013) Evaluation of IL17A expression and of IL17A, IL17F and IL23R gene polymorphisms in Brazilian individuals with periodontitis. Human Immunology 74, 207-214.

Schaefer, A.S., Richter, G.M., Nothnagel, M., Laine, M.L., Noack, B., Glas, J., Schrezenmeir, J., Groessner-Schreiber, B., Jepsen, S., Loos, B.G. \& Schreiber, S. (2010) COX-2 Is associated with periodontitis in Europeans. Journal of Dental Research 89, 384-388.

Soedarsono, N., Rabello, D., Kamei, H., Fuma, D., Ishihara, Y., Suzuki, M., Noguchi, T., Sakaki, Y., Yamaguchi, A. \& Kojima, T. (2006) Evaluation of RANK/RANKL/OPG gene polymorphisms in aggressive periodontitis. Journal of Periodontal Research 41, 397-404.

Sun, X., Meng, H., Shi, D., Xu, L., Zhang, L., Chen, Z., Feng, X. \& Lu, R. (2011) Analysis of plasma calprotectin and polymorphisms of $\mathrm{S} 100 \mathrm{~A} 8$ in patients with aggressive periodontitis. Journal of Periodontal Research 46, 354-360.

Zhong, Q.F., Ding, C., Wang, M.L., Sun, Y. \& Xu, Y. (2012) Interleukin-10 gene polymorphisms and chronic/aggressive periodontitis susceptibility: A meta-analysis based on 14 case-control studies. Cytokine 60, 47-54. 